\title{
The Potential Economic Effects of COVID-19 on Expenditure to the Services Sector and Employment by Age and Gender in Indonesia
}

\author{
Carunia Mulya Firdausy ${ }^{1,2 *}$, Pihri Buhaerah ${ }^{2}$ \\ ${ }^{1}$ Professor of Economics, Faculty of Economics and Business, Universitas Tarumanagara, Jakarta - 11470, Indonesia \\ ${ }^{2}$ Research Associate, Economic Research Centre - Indonesian Institute of Sciences, Jakarta - 12710, Indonesia \\ *Corresponding author. Email: caruniaf@pps.untar.ac.id
}

\begin{abstract}
The pandemic Covid-19 has made the Indonesian economy fall into recession in 2020. This paper, by using the National Social-Economic Survey (SUSENAS) 2014 and 2018 published by the Central Bureau of Statistics, aimed at examining the potential economic effects of the Covid-19 on the expenditure to the services sector and employment sector by age and gender. The study found that the potential effects of Covid19 on the expenditure on the services sector by the age groups will be deeper for both males and females in the age groups between 25 and 34 years old and the age group of 60 years old. The potential economic effects of Covid-19 on employment in the primary sector by age group and gender will be in the age groups between 35 and 54 years old, while in the secondary and tertiary sectors will tend to be in the age groups between 20 to 44 years old and the age groups between 20 to 49 years old. These findings suggest that the above age groups and gender need to tight their household expenditure on the services sector and seek less physicalcontact business activities as their source of income during the Covid-19 pandemic. If they are entrepreneurs and managers, they need to reposition, retarget, and accelerate the digital marketing technology of their business. However, caveats should be applied in that they should not do any logical fallacies that can harm their decision makings, including hasty generalization, appeal to ignorance, and argument from the authority to name just three. Thus, entrepreneurs and managers should do detailed research before making a decision.
\end{abstract}

Keywords: Covid-19, employment structure, expenditure to the services sector, age group, gender, Indonesia

\section{INTRODUCTION}

Indonesia has been known as one of the largest economies in the world and an important member of the G-20 before the Covid-19 pandemic outbreak in early March 2020. This country was able to increase its GDP almost six times since 2000 from 165 billion USD to 1 trillion USD in 2018. The economy also experienced demographic changes.

In terms of the age structure, the largest proportion of the population was in the age groups between 25 and 54 years (42.4 percent), followed by the age groups of 0-14 (25.9 percent), and age groups of $15-24$ years (16.8 percent). The age groups of 55 - 64 years and 65 years above were about 8.6 percent and 6.3 percent respectively [11].

Apart from demographic changes, there has also been a structural transformation from primary and secondary sectors to the tertiary sector. This structural transformation has contributed to the primary and secondary sectors declining significantly [5] [7].

As the Covid-19 pandemic outbroke in early March 2020, the above achievements changed drastically. The reason is that the demand and production sides of the economy could not operate properly. In terms of aggregate demand, for example, household consumption, which before the Covid-19 pandemic was the main support for economic growth, contracted deeply. From the production side, the economic growth contraction also occurred due to delayed production machinery [13].

With the brief rationale background above, this study aimed at examining the potential economic effects of the Covid-19, particularly, on the expenditure to the services sector and employment structure by age groups and gender. The data used to estimate the potential economic effects originated from the National Social-Economic Survey (Susenas) 2014 and 2018 published by the Central Board of Statistics [3] [5]. It is worth noting that advanced studies in the literature which directly examine these research questions, are not yet available in Indonesia.

\subsection{Related Work}

There have been many theoretical foundations of this study. This includes [18] [19] [20] and [21]. Recent empirical studies directly examining these research questions have not yet been available. However, the studies particularly examining the implication of the demographic and structural changes on expenditure to the 
services sector and employment have been conducted by [1] [2] [9] [10] [12] just to name five studies. Thus, the originality of this study is no-doubt.

\subsection{Our Contribution}

This paper has novelty especially as it aims at examining the potential economic effects of Covid-19 on expenditure to the services sector and employment by age groups and gender by employing the data of the National SocialEconomic Survey (SUSENAS) 2014 and 2018. The rationale and the research gap of these studies were explained briefly as the background of the analysis. This study also gives remarks to entrepreneurs and managers to avoid logical fallacies before adapting and reshaping their business strategies.

\subsection{Paper Structure}

This paper is structured into 3 sections. The first section highlights the brief state-of-the-art of this study including the rationale and the research gap of this study. The second section deals not only with the background addressing data analysis of the potential economic effects of Covid-19 on expenditure to the services sector by age and by gender, but also shows the results and discusses this study's findings of the potential economic effects of Covid-19 on expenditure on the services sector by age and gender, and the potential economic effects of Covid-19 on employment by age and gender. Finally, concluding remarks are drawn in section 3 .

\section{BACKGROUND}

\subsection{The potential economic effects of Covid-19 on expenditure to the services sector by age}

By analyzing the National Socio-Economic Survey data published by the Central Board of Statistics in 2014, it was found that there were almost no significant differences in the percentage of average expenditure to the services sector by age groups. As shown in Table 1, the percentage of average expenditure to the services sector ranged from 12.7 percent to 15.4 percent. This percentage range was not so far above or below the percentage of total average expenditure to the services sector of 13.9 percent. By the age groups, the age group of 15-19 years relatively has a high percentage of average expenditure to services in comparison with other age groups, followed by the age groups of 45-49 and 40-44 years old. The lowest percentage of average expenditure to the services sector was in the age group of 60 years above.

Table 1 Percentage of Average Expenditure to the Services Sector by Age Group in 2014

\begin{tabular}{|c|c|c|c|}
\hline \multirow{2}{*}{ Age Group } & \multicolumn{3}{|c|}{ Average Expenditure on Services Sector / Capita / Month } \\
\cline { 2 - 4 } & Nominal (Rupiah) & Real (CPI) & Percentage \\
\hline $15-19$ & $134,027.00$ & $1,183.77$ & 15.381 \\
$20-24$ & $141,375.20$ & $1,248.68$ & 14.393 \\
$25-29$ & $123,245.10$ & $1,088.55$ & 12.951 \\
$30-34$ & $114,223.60$ & $1,008.86$ & 12.958 \\
$35-39$ & $124,627.00$ & $1,100.75$ & 13.716 \\
$40-44$ & $131,387.60$ & $1,160.46$ & 14.516 \\
$45-49$ & $143,645.00$ & $1,268.72$ & 14.954 \\
$50-54$ & $140,674.90$ & $1,242.49$ & 14.327 \\
$55-59$ & $137,930.20$ & $1,218.25$ & 13.879 \\
$60-64$ & $126,438.40$ & $1,116.75$ & 12.993 \\
$65+$ & $112,517.10$ & 993.79 & 12.656 \\
\hline TOTAL & $123,286.90$ & $1,088.91$ & 13.861 \\
\hline
\end{tabular}

Source: Authors' calculation, based on the Indonesia National Socio-Economic Survey 2014.

In 2018, the average expenditure to the services sector by age group declined significantly. As exhibited in Table 2, the total proportion of average expenditure per capita per month to the services sector by age groups in 2018 declined to almost half of the total average expenditure to the services sector in 2014. There was a surprising fact showed in 2018 that the age groups that have low percentages of average expenditure to the services were not in the age group above 60 years old, but it happened to the age groups of 25-29 years and 30-34 years old. This condition may be due to the fact of the greater contribution of the manufacturing sector to the growth in 2018 which further led to the increasing prices of the services product generated by the services sector [10] [12]. 
Table 2 The Percentage of Average Expenditure to the Services Sector / Capita / Month by Age Group in 2018

\begin{tabular}{|c|c|c|c|}
\hline \multirow{2}{*}{$\begin{array}{c}\text { Age } \\
\text { Groups }\end{array}$} & \multicolumn{3}{|c|}{ Average Expenditure on Services Sector / Capita / Month } \\
\cline { 2 - 4 } $15-19$ & Nominal (Rupiah) & Real (CPI) & Percentage \\
$20-24$ & $105,162.60$ & 787.38 & 7.9982 \\
$25-29$ & $99,892.71$ & 747.92 & 6.5612 \\
$30-34$ & $85,147.23$ & 637.52 & 5.6377 \\
$35-39$ & $82,353.28$ & 616.60 & 5.9251 \\
$40-44$ & $91,178.25$ & 682.68 & 6.7041 \\
$45-49$ & $97,847.42$ & 732.61 & 7.2008 \\
$50-54$ & $108,509.60$ & 812.44 & 7.1879 \\
$55-59$ & $103,003.70$ & 771.22 & 6.6907 \\
$60-64$ & $97,296.46$ & 728.49 & 6.2704 \\
$65+$ & $91,811.86$ & 687.42 & 6.1255 \\
\hline TOTAL & $85,418.79$ & 639.55 & 6.3511 \\
\hline
\end{tabular}

Source: Authors' calculation, based on the Indonesia National Socio-Economic Survey, 2018.

The results above at least suggest two things. First, the expenditure to the services sector by age groups in Indonesia is still low in comparison with those in the developed countries [2]. Second, the higher expenditure to the services sector of the age group between 35 and 49 was not so surprising, as people in the age group have an increasing need to spend their incomes to buy services items (eg. housing, transportation, and health) relatively to the rest of the other age groups [9]. Thus, the potential economic effects of Covid-19 judging from the expenditure to the services sector by the age groups will be deeper in the age groups between 25 and 34 years old and the age group of 60 years above, than any other age group. For the latter, this is because the majority of this age group was in the retirement age.

\subsection{The potential economic effects of Covid-19 on expenditure to the services sector by age and gender}

If the age group data was estimated crossly by gender, the result shows that there have been almost no significant differences in the expenditure to services sector by age groups and by gender in 2014. However, the percentage differences in the expenditure to the services sector were found to be in the age groups between 35 and 44 years old. In these age groups, the percentage of expenditure to the services sector of females was higher than that of males (Table 3).

Table 3 Differences of Expenditure to the Services Sector by Age Groups and Gender, 2014

\begin{tabular}{|c|c|c|c|}
\hline \multirow{2}{*}{ Age Group } & \multicolumn{2}{|c|}{ Services Sector Share $(\%)$} & \multirow{2}{*}{ Differences } \\
\cline { 2 - 3 } & Male & Female & -0.4287 \\
\hline $15-19$ & 15.3351 & 15.7638 & -0.0467 \\
$20-24$ & 14.2713 & 14.3180 & -0.1140 \\
$25-29$ & 12.4133 & 12.5274 & -0.8238 \\
$30-34$ & 12.1353 & 12.9591 & -1.2755 \\
$35-39$ & 12.7624 & 14.0379 & -0.5633 \\
$40-44$ & 13.9548 & 14.5181 & 0.1747 \\
$45-49$ & 14.7365 & 14.5618 & 0.9560 \\
$50-54$ & 14.3591 & 13.4031 & 1.1940 \\
$55-59$ & 13.7317 & 12.5377 & 0.9960 \\
$60-64$ & 12.5869 & 11.5909 & 0.5431 \\
\hline $65+$ & 11.5242 & 10.9812 & -0.1088 \\
\hline Total & 13.4331 & 13.5419 & \\
\hline
\end{tabular}

Source: Authors' calculations, based on the Indonesia National Socio-Economic Survey 
In 2018, the percentage of expenditure to the services sector between males and females by the age groups declined by almost half than in 2014 (Table 4). Judging from this data, the Covid-19 will potentially suffer both males and females in the age groups between 25 and 34 years old and between 55 and 64 years old. This is because the expenditure to the services sector of these age groups and gender was less than 6 percent in comparison to those of other age groups. In the female category, the age groups between 25-29 years and 55 years above have the average expenditure to the services sector between 5.7 percent and 6.0 percent. Meanwhile, in the male category, the average expenditure to the services sector below 6 percent was in the age groups between 25 and 34 years old and between 60 and 64 years old (Table 4).

Table 4 Differences of Expenditure to Services Sector Differences by Age Groups and Gender, 2018

\begin{tabular}{|c|c|c|c|}
\hline \multirow{2}{*}{ Age Group } & \multicolumn{2}{|c|}{ Services Sector Share $(\%)$} & \multirow{2}{*}{ Differences } \\
\cline { 2 - 3 } & Male & Female & -0.6875 \\
$15-19$ & 7.8376 & 8.5250 & -0.4166 \\
$20-24$ & 6.3978 & 6.8144 & -0.5096 \\
$25-29$ & 5.1688 & 5.6784 & -0.9087 \\
$30-34$ & 5.2827 & 6.1913 & -1.0349 \\
$35-39$ & 6.0207 & 7.0556 & -0.3813 \\
$40-44$ & 6.8305 & 7.2117 & 0.0565 \\
$45-49$ & 7.0487 & 6.9923 & 0.3273 \\
$50-54$ & 6.7089 & 6.3817 & 0.3025 \\
$55-59$ & 6.2527 & 5.9502 & 0.0002 \\
$60-64$ & 5.8990 & 5.8988 & 0.1110 \\
$65+$ & 6.1651 & 6.0541 & -0.2561 \\
\hline Total & 6.4209 & 6.6770 & S \\
\hline
\end{tabular}

Source: Authors' calculations, based on the National Socio-Economic Survey, $2014-2018$.

\subsection{The Potential Economic effects of Covid-19 on employment by age}

The potential economic effects of Covid-19 on employment by age depending on the use of data. If the 2014 National Socioeconomic Survey was used, the potential economic effects will vary between the employment sector and the age groups. In the primary sector, the largest potential effects will be in the age groups between 30 and 54 years old. This is simply because the proportion of employment in each of these age groups was above 10 percent. The total percentage of employment in the primary sector of these age groups was 56.6 percent. In the secondary sector, the potential effects of Covid-19 will be in the age group between 20 and 44 years old. The same argument as above is because the percentage of employment in this sector for these groups was above 10 percent. The total proportion of this age group was 72.5 percent. In the tertiary sector, the potential effects of Covid-19 will be on the age groups between 20 and 49 years old. The argument behind this is simply because of the proportion of the age groups in this sector above 10 percent. The total proportion of these age groups in the tertiary sector was 77.5 percent (Table 5).

Table 5 Percentage of Employment by Economic Sectors and by Age Groups in 2014

\begin{tabular}{|c|r|r|r|r|}
\hline \multirow{2}{*}{ Age Group } & \multicolumn{4}{|c|}{ Economic Sectors } \\
\cline { 2 - 4 } & Primary & Secondary & Tertiary & Total \\
\hline $15-19$ & 5.10 & 6.79 & 4.57 & 5.03 \\
$20-24$ & 8.60 & 17.87 & 12.40 & 11.78 \\
$25-29$ & 9.37 & 15.51 & 14.18 & 12.70 \\
$30-34$ & 10.27 & 14.29 & 14.18 & 12.85 \\
$35-39$ & 11.81 & 13.63 & 13.44 & 12.90 \\
$40-44$ & 12.08 & 11.17 & 12.50 & 12.19 \\
$45-49$ & 11.65 & 8.24 & 10.82 & 10.79 \\
$50-54$ & 10.11 & 5.70 & 8.28 & 8.58
\end{tabular}




\begin{tabular}{|c|r|r|r|r|}
$55-59$ & 8.31 & 2.95 & 5.03 & 5.89 \\
$60-64$ & 5.78 & 1.95 & 2.55 & 3.58 \\
$65+$ & 6.92 & 1.91 & 2.05 & 3.70 \\
\hline TOTAL & $\mathbf{1 0 0 . 0 0}$ & $\mathbf{1 0 0 . 0 0}$ & $\mathbf{1 0 0 . 0 0}$ & $\mathbf{1 0 0 . 0 0}$ \\
\hline
\end{tabular}

Source: Authors' calculation, based on the Indonesia National Socio-Economic Survey of 2014.

By using the 2018 National Socio-Economic Survey data, the potential economic effects of Covid-19 on the employment sector and by age will be much very different than by using in the 2014 survey data. By using the 2018 data, the potential economic effects of Covid-19 on employment in the primary sector by age group will be in the age groups between 35 and 54 years old. This judgment is logically based on the fact that the percentage of employment for each of these age groups was above 10 percent. Similarly, the potential economic effect of Covid19 on employment in the secondary sector will tend to be in the age groups between 20 to 44 years old. In the tertiary sector, the potential economic effects will be on employment in the age groups between 20 to 49 years old (Table 6).

Table 6 Percentage of Employment by Economic Sectors and by Age Groups in 2018

\begin{tabular}{|c|r|r|r|r|}
\hline \multirow{2}{*}{ Age groups } & \multicolumn{3}{|c|}{ Economic Sectors } \\
\cline { 2 - 4 } & Primary & Secondary & Tertiary & Total \\
\hline $15-19$ & 3.86 & 5.17 & 3.49 & 11.61 \\
$20-24$ & 7.75 & 15.75 & 13.64 & 10.96 \\
$25-29$ & 8.81 & 15.88 & 13.59 & 12.44 \\
$30-34$ & 9.59 & 13.86 & 13.86 & 12.39 \\
$35-39$ & 11.35 & 13.59 & 12.59 & 13.05 \\
$40-44$ & 11.82 & 11.97 & 11.28 & 12.27 \\
$45-49$ & 11.79 & 9.11 & 8.84 & 11.16 \\
$50-54$ & 10.66 & 6.41 & 5.85 & 9.09 \\
$55-59$ & 9.26 & 4.01 & 2.98 & 6.67 \\
$60-64$ & 6.98 & 2.24 & 2.28 & 4.12 \\
$65+$ & 8.12 & 1.99 & $\mathbf{1 0 0 . 0 0}$ & 4.04 \\
\hline TOTAL & $\mathbf{1 0 0 . 0 0}$ & $\mathbf{1 0 0 . 0 0}$ & $\mathbf{1 0 0 . 0 0}$ \\
\hline
\end{tabular}

Source: Authors' calculation, based on the Indonesia National Socio-Economic Survey in 2018.

\subsection{Potential economic effects of COVID - 19 on employment between Males and Females}

By using the 2014 National Socio-Economic Survey data, the potential economic effects of Covid-19 on male employment in the primary sector will be mostly on the age groups between 30 and 54 years. Again, the logical reason for this is simply because the proportion of employment in each of these age groups was above 10 percent. The total percentage of employment in these age groups in the primary sector was 56 percent. In the secondary sector, the potential economic effects of Covid19 on male employment were in the groups of age between 20 and 44 years old, while in the tertiary sector the effects will be on the age groups between 20 and 49, for the same logical reason (Table 7).

Table 7 Percentages of Male Employment by Economic Sectors and by Age Group in 2014

\begin{tabular}{|c|r|r|r|r|}
\hline \multirow{2}{*}{$\begin{array}{c}\text { Age } \\
\text { Groups }\end{array}$} & \multicolumn{3}{|c|}{ Economic Sectors } \\
\cline { 2 - 5 } & Primary & \multicolumn{1}{|c|}{ Secondary } & Tertiary & Total \\
\hline $15-19$ & 5.13 & 6.82 & 4.58 & 5.04 \\
$20-24$ & 8.64 & 17.88 & 12.42 & 11.81 \\
$25-29$ & 9.36 & 15.51 & 14.17 & 12.70 \\
$30-34$ & 10.26 & 14.30 & 14.17 & 12.85 \\
$35-39$ & 11.82 & 13.59 & 13.46 & 12.92 \\
$40-44$ & 12.08 & 11.13 & 12.51 & 12.19 \\
$45-49$ & 11.67 & 8.27 & 10.84 & 10.80 \\
$50-54$ & 10.12 & 5.72 & 8.25 & 8.57
\end{tabular}




\begin{tabular}{|c|r|r|r|r|}
$55-59$ & 8.28 & 2.93 & 5.03 & 5.88 \\
$60-64$ & 5.76 & 1.93 & 2.55 & 3.57 \\
$65+$ & 6.88 & 1.91 & 2.03 & 3.67 \\
\hline TOTAL & $\mathbf{1 0 0 . 0 0}$ & $\mathbf{1 0 0 . 0 0}$ & $\mathbf{1 0 0 . 0 0}$ & $\mathbf{1 0 0 . 0 0}$ \\
\hline
\end{tabular}

Source: Authors' calculation, based on the Indonesia National Socio-Economic Survey 2014 \& 2018

However, if the judgment used to examine the potential economic effects of Covid-19 on male employment was based on the 2018 survey data, then the data showed that there were no differences in the potential economic effects on the male employment by age groups, especially in the secondary and tertiary sector (Table 8 ). This is because the percentage of male employment by age in these two sectors was the same as in the 2014 survey data (Table 7). The only difference was found in the male employees of the primary sector. As can be seen in Table 8, the percentage of male employment in this sector, especially for the age group between 30 and 34 years old has been slightly decreasing from 10.3 percent in 2014 to 9.6 percent in 2018. Therefore, by using the 2018 survey data, the potential economic effects of Covid-19 will be much less proportionally for male employment in the primary sector than in the secondary and tertiary sectors.

Table 8 Percentage of male employment by economic Sectors by age group in 2018

\begin{tabular}{|c|r|r|r|rr|}
\hline \multirow{2}{*}{ Age group } & \multicolumn{5}{|c|}{ Economic Sectors } \\
\cline { 2 - 6 } & Primary & Secondary & Tertiary & Total \\
\hline $15-19$ & 3.87 & 5.19 & 3.49 & & 3.83 \\
$20-24$ & 7.77 & 15.77 & 11.63 & & 10.97 \\
$25-29$ & 8.83 & 15.93 & 13.63 & & 12.45 \\
$30-34$ & 9.60 & 13.85 & 13.59 & & 12.39 \\
$35-39$ & 11.36 & 13.59 & 13.86 & & 13.05 \\
$40-44$ & 11.81 & 11.96 & 12.60 & & 12.27 \\
$45-49$ & 11.79 & 9.09 & 11.29 & & 11.16 \\
$50-54$ & 10.65 & 6.41 & 8.84 & & 9.09 \\
$55-59$ & 9.25 & 3.99 & 5.84 & & 6.65 \\
$60-64$ & 6.97 & 2.23 & 2.97 & & 4.11 \\
$65+$ & 8.11 & 1.98 & 2.27 & & 4.03 \\
\hline TOTAL & 100.00 & 100.00 & 100.00 & & 100.00 \\
\hline ST
\end{tabular}

Source: Authors' calculation, based on the Indonesia National Socio-Economic Survey 2014 and 2018.

The potential economic effects of Covid-19 on the female employment by sector and by age group was surprisingly the same as for the male employment discussed above. As given in Table 9, by using the 2014 survey data, most female employment in the primary sector was in the age groups between 30 and 54 years old. Similarly, female employment in the secondary sector was mainly in the age groups between 20 and 44 years old. Whilst in the tertiary sector, the female employment was in the age groups between 20 and 49 years old. This phenomenon suggests that the potential economic effects of Covid-19 on female employment will be harder for these age groups than those of other age groups in each employment sector [12].

Table 9 Percentage of Female Employment by Economic Sectors and by Age Group in 2014

\begin{tabular}{|c|r|r|r|r|}
\hline \multirow{2}{*}{ Age groups } & \multicolumn{4}{|c|}{ Economic Sectors } \\
\cline { 2 - 5 } & \multicolumn{1}{|c|}{ Primary } & Secondary & Tertiary & Total \\
\hline $15-19$ & 5.14 & 6.79 & 4.58 & 5.05 \\
$20-24$ & 8.62 & 17.97 & 12.44 & 11.83 \\
$25-29$ & 9.36 & 15.44 & 14.19 & 12.69 \\
$30-34$ & 10.29 & 14.36 & 14.21 & 12.89 \\
$35-39$ & 11.87 & 13.61 & 13.44 & 12.93 \\
$40-44$ & 12.14 & 11.18 & 12.54 & 12.23 \\
$45-49$ & 11.72 & 8.21 & 10.82 & 10.80
\end{tabular}




\begin{tabular}{|c|r|r|r|r|}
$50-54$ & 10.10 & 5.70 & 8.27 & 8.57 \\
$55-59$ & 8.27 & 2.93 & 5.01 & 5.86 \\
$60-64$ & 5.71 & 1.91 & 2.52 & 3.53 \\
$65+$ & 6.79 & 1.91 & 1.98 & 3.62 \\
\hline TOTAL & 100.00 & 100.00 & 100.00 & 100.00 \\
\hline
\end{tabular}

Source: Authors' calculation, based on the Indonesia National Socio-Economic Survey 2014 and 2018.

The potential economic effects of Covid-19 on female employment by the age group will also be the same by using the 2018 survey data. The only difference in the 2014 survey data was in the primary sector. In this sector, the potential economic effects will be on female employment in the age groups between 35 and 54 years old. While by using the 2014 survey data, the potential economic effects of Covid-19 in this sector will include female employment in the age group of 30 and 34 years old (Table 10). These findings support the previous studies conducted by [10] and [12].

Table 10 Percentage of Female Employment by Economic Sectors and by Age Group in 2018

\begin{tabular}{|c|r|r|r|r|}
\hline \multirow{2}{*}{ Age groups } & \multicolumn{3}{|c|}{ Economic Sectors } \\
\cline { 2 - 4 } & Primary & Secondary & Tertiary & \multicolumn{1}{|c|}{ Total } \\
\hline $15-19$ & 3.87 & 5.16 & 3.48 & 3.82 \\
$20-24$ & 7.77 & 15.78 & 11.63 & 10.98 \\
$25-29$ & 8.82 & 15.92 & 13.66 & 12.46 \\
$30-34$ & 9.61 & 13.88 & 13.61 & 12.42 \\
$35-39$ & 11.37 & 13.60 & 13.88 & 13.07 \\
$40-44$ & 11.85 & 11.98 & 12.60 & 12.29 \\
$45-49$ & 11.82 & 9.11 & 11.27 & 11.16 \\
$50-54$ & 10.66 & 6.38 & 8.83 & 9.07 \\
$55-59$ & 9.23 & 3.99 & 5.83 & 6.64 \\
$60-64$ & 6.96 & 2.24 & 2.96 & 4.10 \\
$65+$ & 8.03 & 1.98 & 2.25 & 3.99 \\
\hline TOTAL & 100.00 & 100.00 & 100.00 & 100.00 \\
\hline
\end{tabular}

Source: Authors' calculation, based on the Indonesia National Socio-Economic Survey 2014 and 2018

\section{CONCLUSION}

The study at least found the following. First, the potential economic effects of Covid-19 judging from the expenditure to the services sector by the age groups and gender will be deeper in the age groups between 25 and 34 years old and the age group of 60 years above than that in any other age group.

Second, the potential economic effects of Covid-19 on employment in the primary sector by age group and gender will be in the age groups between 35 and 54 years old. In the secondary and tertiary sectors, the effects will be on the age groups between 20 to 44 years old and the age groups between 20 to 49 years old.

There is no single policy measure to minimize the potential economic effects of Covid-19 on the expenditure to the services sector and the employment structure by age and gender. Apart from directing its fiscal and monetary policies to the age and gender above, the government also needs to accelerate the digital business marketing technology for the bulk of micro, small, and medium enterprises.

The age groups and gender that were potentially hit badly by the covid-19 pandemic should tight their expenditure to the services sector and seek employment sector or business activity that has less physical contact to the consumers during the Covid-19 pandemic. If they are entrepreneurs and managers, they need to reposition, retarget, and accelerate the digital marketing technology of their business.

However, caveats should be applied in that they should not do any logical fallacies that can harm their decision makings, including hasty generalization, appeal to ignorance, and argument from the authority, to name just three. 


\section{REFERENCES}

[1] D. Akst, Automation anxiety: where have all the jobs gone? The Wilson Quarterly, 37 (3), (2013) 60-74. http://www.jstor.org/stable/wilsonq.

[2] L. Brembilla, The demographic of Structural Change. Paper presented at the 24th Conference of the Society of Computational Economics and Finance, October 31, 2018.

[3] Central Board of Statistics, National Socioeconomic Survey 2014, BPS, Jakarta, 2015.

[4] Berita Resmi Statistik. Agustus, BPS. Jakarta, 2018.

[5] Berita Resmi Statistik, September, BPS, Jakarta, 2019.

[6] , Social-Economic National Survey 2018. BPS, Jakarta, 2019.

[7] , Keadaan Angkatan Kerja di Indonesia Agustus 2016. BPS, Jakarta, 2018.

[8] Centre for Economic Research-Indonesian Institute of Sciences, Outlook Ekonomi Indonesia 2020. Paper presented at LIPI, January 10 (2020), Jakarta.

[9] J. Cravino, A.A. Levchenko, M. Rojas, Population Aging and Structural Transformation, NBER Working Paper Series 26327 National Bureau of Economic Research, Cambridge, (2019).

[10] B. Herrendorf, R. Rogerson, A.Valentinyi, Growth, and structural transformation. Paper prepared for the handbook of economic growth, (2011). https://www.imf.org/external/np/seminars/eng/2013/SP R/pdf/rrog2.pdf

[11] International Labour Organization, Indonesia Jobs Outlook 2017: Harnessing technology for growth and job creation, International Labour Office - Jakarta: ILO, 2017.

[12] S.Khatiwada, C. Lennon, Structural transformation in resource-rich countries: a case of Indonesia and Nigeria. ILO Working Paper, (2017).

[13] Kompas, Kemiskinan : Tumbuhkan Kegiatan Ekonomi di Daerah, Harian Kompas, (2020) 1.

[14] R.M.Solow, A contribution to the theory of economic growth, Quarterly Journal of Economics. 70
(1) (1956) 65-94. DOI:

https://doi.org/10.2307/1884513.Pdf

[15] Indonesia Population in 2020.

https://www.worldometers.info/worldpopulation/indonesia-population. (2020).

[16] United Nations for Development Program (UNDP), Human Development Reports, UNDP, (2019). hdr.undp.org.

[17] World Bank, Economic Update Indonesia: World Bank Upgrades Indonesia to Upper-Middle Income Country (2020). www.indonesia-investment.com

[18] G.S. Becker, Human Capital. University of Chicago Press, (1993).

[19] G. Mankiw, D. Romer, D. Weil, A Contribution to the empirics of Economic Growth, Quarterly Journal of Economics. 106 (1992) 407-437.

[20] T.W. Schultz, The economic Importance of Human Capital in Modernization, Education Economics, 1 (1) (1993) 13-19.

[21] P.Romer, Human Capital and Growth: Theory and Evidence, Carnegie Rochester Conference Series on Public Policy. 32 (1990) 251-286. 